\title{
Influence of Value Co-Creation on Virtual Community Brand Equity for Unichannel vs. Multichannel Users
}

\author{
Natalia Rubio (D), Nieves Villaseñor * and $M^{\text {a }}$ Jesús Yagüe ${ }^{(D)}$ \\ Marketing Department, Universidad Autónoma of Madrid, 28049 Madrid, Spain; natalia.rubio@uam.es (N.R.); \\ maria.yague@uam.es (M.J.Y.) \\ * Correspondence: nieves.villasenor@uam.es
}

Citation: Rubio, N.; Villaseñor, N.; Yagüe, M.J. Influence of Value Co-Creation on Virtual Community Brand Equity for Unichannel vs. Multichannel Users. Sustainability 2021, 13, 8403. https://doi.org/ $10.3390 /$ su13158403

Academic Editors: Marta Frasque and Alejandro Mollá

Received: 30 June 2021

Accepted: 26 July 2021

Published: 28 July 2021

Publisher's Note: MDPI stays neutral with regard to jurisdictional claims in published maps and institutional affiliations.

Copyright: (c) 2021 by the authors. Licensee MDPI, Basel, Switzerland. This article is an open access article distributed under the terms and conditions of the Creative Commons Attribution (CC BY) license (https:// creativecommons.org/licenses/by/ $4.0 /)$.

\begin{abstract}
Value co-creation by users in a virtual community is a key element to encouraging the community's brand equity. This study analyzes the effect of the functional value provided by the virtual community on the two value-co-creation behaviors that occur within it: (1) self-value cocreation and (2) communal value co-creation. Through self-value co-creation, participants co-create value to their own benefit by becoming involved in co-designing their experience. By communal value co-creation, participants co-create value through evaluations, recommendations, and ideas that benefit others. This study also asks whether multichannelity-using various channels to access the virtual community (website and mobile app), as opposed to using a single channel (website or mobile app)- - has a moderating effect on the relationships proposed between value co-creation and brand equity of the virtual community. The analysis is contrasted empirically for the virtual community Tripadvisor with data collected by a research institute via telephone interview. Confirmatory factor analysis and multi-group structural equation modeling techniques were used to assess the proposed model. The study enriches two significant lines of scholarly research, value co-creation and brand equity. It does so in multi-brand virtual contexts in which variety of service brands coexists with the brand of the virtual community, and with users who access the virtual community through one or various channels. The study also contributes to the formulation of business strategies oriented to increasing the brand equity of virtual communities.
\end{abstract}

Keywords: value co-creation; functional value; brand equity; virtual community; multichannelity

\section{Introduction}

Recent reports published by PwC [1] reveal interesting information on consumers' multichannel use in search and shopping processes. According to the study, users in Spain regularly employ the online search for information as a source of inspiration for subsequent shopping. The five online media most used regularly as a source of inspiration in shopping are social networks, multibrand webpages, virtual communities, online price comparison websites, and retailers' individual webpages. It is also important to note that multichannel search behavior and shopping have accelerated due to COVID-19. There is thus a business need to improve the multichannel experience in different interactions with consumers.

In the area of scholarship, study of value co-creation in a multichannel context is currently a priority in marketing research [2]. This entity encourages scholarly research to tackle topics that can increase understanding of "the formation of consumers' preferences for virtual communities" and "the consumer's involvement in the co-creation of products and content through these communities", among other issues.

To date, most academic studies of co-creation in virtual communities have analyzed the phenomenon of co-creation from a unichannel perspective, focusing on the particularities of the platform studied without considering the technology/-ies used to access the platform (i.e., website, mobile app, etc.). This line of research has analyzed co-creation in discussion forums [3,4], on social networks [5], and on applications specializing in videos [6]. In 
another line of research, studies that have incorporated the multichannel perspective into study of virtual communities have not tackled the different facets of value co-creation. They remain limited to analyzing how generation of any manifestation of value co-creation (primarily e-wom) varies depending on the technology the user uses [7]. Our study seeks to fill the gaps identified and to contribute to existing research by providing a comprehensive conceptualization of value co-creation in a virtual community from a multichannel perspective. Thus, conceptualization of co-creation in this study spans different facets of the phenomenon and considers access to the virtual community from different channels.

Although more advanced technologies will continue to emerge and create new opportunities for firm-customer interactions, understanding real customer preferences and personalizing customer co-creation experience will remain a challenge [8]. The findings of previous studies of the role of multichannelity in value co-creation are inadequate to explain how the use of various technologies affects the virtual community user, an issue critical to creation of the community's brand equity. This study examines whether multichannelity vs. unichannelity encourages the positive impact of value co-creation on the virtual community's brand equity and whether this positive impact differs across channels.

The success of virtual communities depends greatly on achieving active participation of members and recommendation of the community to third parties [9]. Brand equity is a clear indicator of the achievement of these objectives-hence its inclusion as an important dependent variable in our study. Users' perception of the community's brand equity will ensure the community's sustainability in the long term. The goal of the virtual community's sustainability is no small matter in our new era [10]. Now more than ever, consumers make decisions to buy and/or consume based on ethical and/or environmental questions. This trend can be seen in different sectors, such as the growth of the vegan movement in diet or the purchasing of electric vehicles in the automotive industry. Such sustainable behavior appears in the virtual community as well. Users co-create value motivated not only by the desire to create value for themselves (self-value co-creation) but by the benefit they can contribute to other participants in the virtual community [11,12]. Users in the virtual community participate in co-creation processes to be useful to and/or to provide a service and contribute to the wellbeing of other actors in the virtual community (communal value co-creation). This study's treatment of co-creation shows that it is a process that contributes to sustainability of the ecosystem in which it takes place-in this case, the virtual community.

To date, most published studies of value co-creation in the digital environment [4] have been performed using the theoretical framework of Service-Dominant Logic (hereafter SDL) $[13,14]$. Based on the premises of this new logic, organizations do not create and deliver value to passive consumers; rather, value is co-created or "jointly created" by multiple actors, such as stakeholders, firms, and customers, always including the beneficiary.

Value co-creation has been studied extensively within the framework of SDL. Research has tackled the validity and adaptability of its dimensions in the different digital contexts $[5,15]$ and identified both its antecedents and its results. Studies of antecedents can be divided into those that focus on characteristics of the environment (e.g., interactivity, reliability of the information) that encourage co-creation and those that identify individuals different motivations for participating in the co-creation process [16-19]. In analyzing the results of value co-creation, studies stress its effect on variables connected to satisfaction, commitment, loyalty, and trust, among other topics [20-25]. Other recent studies tackle antecedents and results simultaneously when analyzing contexts of specific services [26].

To enrich the line of research on value co-creation within the framework of SDL, this study proposes the following questions: To what extent does the perceived functional value of a virtual community encourage value co-creation behavior in its users? As mentioned above, value co-creation involves multiple actors in a virtual community. Therefore, can one differentiate between self-value co-creation behaviors (for the beneficiary of the experience) and communal-value co-creation behaviors (for the other actors, e.g., consumers, firms)? 
Do the different co-creation behaviors increase the virtual community's brand equity? Does the effect of value co-creation on brand equity differ between multichannel and unichannel users?

To answer these questions, the next section presents a summary of the relevant literature and the research hypotheses. The data and research methods are then presented, followed by a discussion of the main findings and managerial recommendations.

\section{Theoretical Background}

\subsection{Co-Creation Behaviors in Virtual Communities}

Prior research suggests that value co-creation is a multidimensional concept $[27,28]$. The first studies of value co-creation in the digital environment explained this concept through one or two components related to the user's search for content and proactive participation, generating and sharing content in order to take part in discussions as well as give feedback and advice on products and/or services to other users of the virtual community [3,4,15,29-31].

Since virtual communities are service ecosystems that include not only consumers but also suppliers of the service, some studies incorporate co-innovation as another dimension of value co-creation. Here, co-innovation is a component of the user's voluntary participation in the platform by providing managers with ideas on how to improve the services they deliver (users propose novel services, identify market trends, identify new types of users, etc.) [32,33].

More recent studies of value co-creation also draw on the relationship literature to add new dimensions to the component of the user's voluntary participation in the platform as it relates to connectedness. In other words, users of virtual communities also participate in these communities to socialize, connect, and interact with other participants $[27,28,34]$.

Based on the review performed, this study proposes two components of value cocreation in virtual communities: self-value co-creation and communal-value co-creation. Self-value co-creation emerges through the user's involvement in making the value proposition [13]. Self-value co-creation is part of the co-creation related to the user's participation in developing the value proposition and designing service provision [34]. For example, in virtual communities of travelers, self-value co-creation occurs when the user participates in designing his or her leisure experience-for example by searching for ideas in the virtual community to organize that experience.

The component of communal-value co-creation-the user's active participation in the virtual community-materializes in recommending products/services to help other members of the community, sharing ideas on how to improve the services housed in the community [31], etc. These actions help to enrich and strengthen the community through its members' interactions [28].

\subsection{Perceived Functional Value as an Antecedent of Value Co-Creation}

Studies of the antecedents of value co-creation in the framework of Social Exchange Theory argue that people who invest more effort in any activity-that is, people who participate actively in the organization, development, and/or evaluation of that activitydo so because they are motivated by the benefits or value they obtain in exchange and/or generate for others [35]. According to the conceptualization of value by [36] and this concept's significant subsequent empirical development, any behavior-whether prepurchase/pre-consumption or post-purchase-responds, on the one hand, to utilitarian or functional perceptions (functional value) [37] and, on the other, to hedonic perceptions or perceptions of entertainment (hedonic value). This study focuses on the functional dimension of the value that the virtual community provides to its users. This value serves as a lever on which the managers can act directly. For example, virtual communities have tools within their reach to modify the functional value of the platform as perceived by its users (e.g., functionalities that permit a higher level of personalization of the service the platform provides). In this context, perceived functional value is defined as the customer's 
evaluation of how efficient and useful the virtual community has been in meeting his/her goal [37].

The virtual community facilitates the exchange of operant resources (e.g., information, knowledge, skills) that improve the perceived functional value for the platform. Thanks to these resources, users feel they can make better decisions, and this feeling fosters a higher degree of self-value co-creation [28] and of communal-value co-creation, or willingness to cooperate with the other actors in the virtual community [38]. Cooperation can materialize in recommendations to other users about products/services with which users have had good experiences [39]. It can also involve communication about service errors and suggestions for improvement to the firms housed on the virtual platform [10]. Based on the foregoing, we propose:

Hypothesis 1a (H1a). Perceived functional value positively influences self-value co-creation in the virtual community.

Hypothesis $1 \mathbf{b}(\mathbf{H 1 b})$. Perceived functional value positively influences communal-value cocreation in the virtual community.

\subsection{Brand Equity as a Result of Value Co-Creation}

The concept of brand equity (BE) was popularized in the late 1980s and early 1990s, beginning with pioneering studies by [40-42]. BE is considered as one of the most valuable intangible assets organizations can have, hence the importance of developing marketing strategies that help to increase BE. This study considers it important to incorporate virtual community BE as the dependent variable in the model, since BE is essential for differentiating the platform from competitors to achieve greater preference for it and a larger number of users, ultimately ensuring its long-term survival.

The study of BE is undertaken from a dual perspective [43], financial and consumerbased brand equity (CBBE). From the financial perspective, BE can be estimated as the incremental cash flows and asset values that accrue to a brand [44-47]. The integrative perspective relates CBBE to BE measured from a sales perspective [48]. From the consumer's perspective, we highlight the modeling of BE by [41,42]. Ref. [41] defines BE as a set of assets and liabilities associated with the brand name and symbology that can be managed to create value. It has five components: brand awareness, brand associations, perceived quality, and degree of loyalty generated, as well as other generic elements classified as "other assets attributable to the brand," such as patents, know-how, etc. For [42], BE is part of brand knowledge in terms of brand awareness, as well as brand associations (characteristics, benefits, and attitudes). This study analyzes BE from the consumer's perspective (CBBE). A long line of research has developed on the factors that affect the construction of $\mathrm{BE}$ and its components, both those linked to improving the consumer's brand experience [49] and the implementation of more effective conventional and/or digital marketing strategies [50-53].

Little research has focused on the positive relationship between value co-creation and CBBE [54-56]. Studies in the B2B environment confirm this relationship [57], as do studies in the tourist environment $[55,58,59]$. Ref. [57] propose a theoretical model for virtual communities based on a review of the literature and on good management practices, indicating that co-innovation activities on virtual platforms generate $\mathrm{BE}$ for these platforms. In another study of virtual communities, [20] confirm that value co-creation in a virtual community of travelers contributes to generating BE for suppliers of the services housed on the platform. This study proposes that the greater the co-creation by users in the virtual community of travelers (both on the personal level, using the platform to design their consumption experiences and on the level of other users, using the platform to make comments, help others, contribute ideas, etc.), the larger the CBBE virtual community will be, as numerous studies like [60] confirm that the quantity, quality, and updating 
of information in the virtual community contribute to increasing its levels of use and preference-both indicators of its BE. Based on the foregoing, we propose:

Hypothesis 2a (H2a). Self-value co-creation in the virtual community positively influences its $C B B E$.

Hypothesis $\mathbf{2 b}(\mathbf{H} 2 \mathbf{b})$. Communal-value co-creation in the virtual community positively influences its $C B B E$.

\subsection{Moderating Effect of Multichannelity on the Proposed Model}

This study draws on "niche theory" to propose that multichannelity can exert a moderating effect on the relationships established between value co-creation in the virtual community and the community's CBBE. Ref. [61] used this theory to argue that users who are in a context where they can choose among different channels and who experience a dilemma about which channel to use will choose based on the utility each channel provides, depending on the activity they are going to perform, how long it will take, etc. It could thus happen that different channels coexist or that some channels replace others. Niche theory has met with widespread acceptance in modeling that analyzes multichannelity to explain the consumer's behavior. As new channels have been developed, niche theory has been used to explain their coexistence. Based on this theory, research has studied coexistence of interactive and traditional media [62], as well as the simultaneous use of mobile Internet, PC Internet, and traditional media [7].

Studies like those by $[35,63]$ confirm that multichannelity in virtual communities conditions users' type of participation. For virtual communities of users, the authors of [64] stress that variables such as perceived ease of use and ubiquity of the medium, among others, determine which channel is preferred for sharing opinions, searching for information, etc. For example, using the cellphone gives greater ubiquity and flexibility in spacetime than using the desktop computer [7]. These factors favor the frequency with which this channel is used in a virtual community to perform simple, immediate tasks, such as searching for information on a restaurant at a tourist destination as dinnertime approaches. Not all users of a virtual community are multichannel users, however; many use the community through one channel only. Differences may exist between these two types of users, for example, in the effect on BE of co-creation behaviors in the virtual community.

Prior experience in the use of a single channel reduces the costs of learning and anxiety when using a specific technology, while also increasing satisfaction with the use experience [65]. Co-creation behaviors generally imply users' dedication and involvement, both when they self-value co-create in advance activities that they will perform at a destination and when they participate actively in recommending, generating, and sharing feedback about specific activities with other users. Unichannel users of a virtual community must, however, have more in-depth specialized knowledge of the channel they use than multichannel users, whose unichannel knowledge may be more limited. Both considerations suggest the possibility that co-creation will have a stronger effect on BE in unichannel than in multichannel users. We have no found research studies, however, that analyze the moderating role of multichannelity vs. unichannelity in the relationship of co-creation to $\mathrm{BE}$. Based on the preceding arguments, this study poses the following H3:

Hypothesis 3 (H3). The relationship established between co-creation behaviors in the virtual community and the community's CBBE is significantly more intense for unichannel users (website or mobile app) than for multichannel users.

Figure 1 presents the theoretical model proposed. 


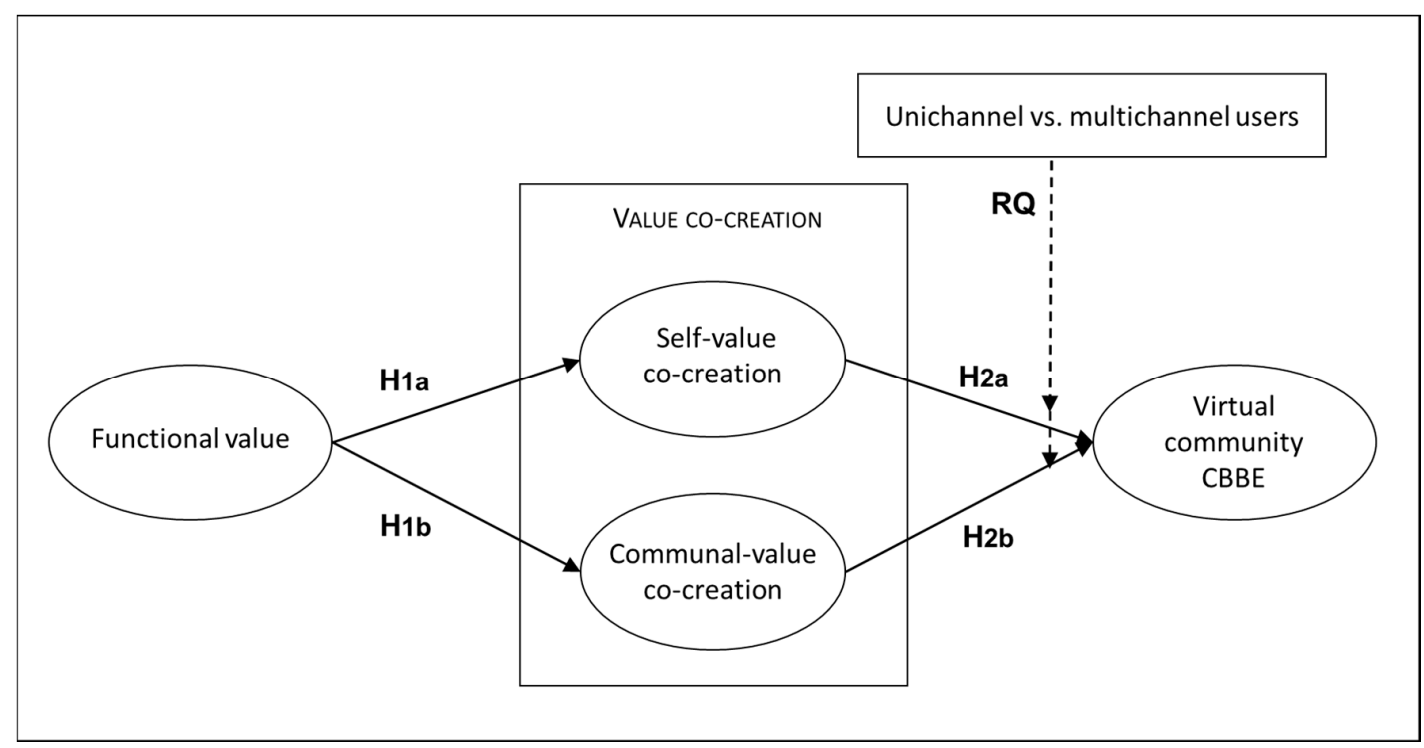

Figure 1. Theoretical Research model.

\section{Methodology}

\subsection{Data Collection and Sample}

To achieve the study goals, we used a market research institute to obtain the information via telephone survey of a valid sample of 600 Tripadvisor users. The sampling error was $4 \%$. All respondents fulfilled the requirement of having commented at least once in the Tripadvisor virtual community on their experiences with any service (restaurant, flight, hotel, or lodging). The market research institute has panels of consumers and selection and validation processes that guarantee the representativeness and validity of the information obtained.

The sample profile is balanced by gender, with $50.3 \%$ women and $47.3 \%$ men. The respondents' ages were primarily in the ranges of 36-50 (37.2\%) and 26-35 (29\%). Nearly half had studied at the university (49.5\%), 51.8\% had net monthly incomes of EUR 1000-2000, and the most common family type was the family with no children, $(41 \%)$, followed by family with one child $(23.3 \%)$, and family with two children $(19.5 \%)$. As to frequency of comments and categories of services on which the respondents commented, $45.2 \%$ of the survey respondents comment at least $50 \%$ of the times they use the platform, and they comment primarily on hotels $(74.2 \%)$ and restaurants $(49.5 \%)$.

\subsection{Measurement Scales}

The items used to measure the concepts were obtained by adapting scales used previously in the academic literature. The scale for perceived functional value was adapted from [66]. To analyze co-creation behaviors, users' self-value co-creation through coproduction behaviors was measured by adapting the items used in the study by [28]. Users' communal-value co-creation through active participation in the virtual community was measured by adapting the scales from $[1,31,67]$. Finally, virtual community CBBE was measured using the four-item unidimensional direct measure in [68] as a reference.

All scales were measured using 11-point Likert scales from 0 (disagree completely) to 10 (agree completely). To measure the moderating variable on the trait of multichannel user of the virtual community, we used a single question that asked individuals in the sample to indicate whether they participated in Tripadvisor's virtual community by using only the website, only the mobile app, or both channels.

The techniques used to analyze the information were, first, a descriptive analysis of the model variables and, second, a study analysis conducted using covariance-based confirmatory factor analyses and structural equation modeling with AMOS 26 software. This analysis used the data aggregated for all virtual community users in the study $(n=600)$. 
Finally, multi-group analysis of the structural modeling of covariance was performed to determine the moderating effect of multichannelity on the proposed model. For the multigroup analysis, the users of the virtual community were divided into two segments based on the channel used-those who used a single channel to participate in the platform, whether only website or only mobile app $(n=357)$, versus those who used both channels $(n=243)$.

\section{Results}

\subsection{Measurement Model}

We confirmed the quality of the measurement scales for each sample, as recommended by [69]. The confirmatory factor analysis performed showed very satisfactory fit in both samples for modeling the four factors proposed. In the sample of unichannel users of the virtual community (website or mobile app), the relationship $\chi^{2} /$ d.f. $=1.47$ was below the maximum threshold of 2 recommended by [70]. The values of the CFI and AGFI were 0.99 and 0.93 , respectively, higher than the minimum value of 0.9 recommended by [70]. The RMSEA value was 0.04 , lower than the maximum value of 0.06 proposed by [71]. In the sample of multichannel users of the virtual community (website and mobile app), the values obtained were also within the limits recommended in the academic literature $\left(\chi^{2} /\right.$ d.f. $=1.80, \mathrm{CFI}=0.97, \mathrm{AGFI}=0.89$, and RMSEA $\left.=0.05\right)$.

Table 1 presents the results for reliability and validity in both samples. In all cases, the statistics used for reliability - the Alpha Cronbach and composite reliability-were higher than the minimum value of 0.70 [72]. In all cases, the variance extracted was greater than or equal to a variance of 0.5 , and all items had sufficient convergent validity, since all the parameters were statistically significant.

Discriminant validity was also confirmed in both samples. Table 2 shows that the root of the percentage of variance extracted for each construct is higher in all cases than the correlation between each pair of concepts.

Finally, we examined measurement invariance between the two groups, as follows. First, we performed multigroup confirmatory analysis. The results showed satisfactory fit $\left(\chi^{2}=280.94 ;\right.$ d.f. $=152 ; \chi^{2} /$ d.f. $=1.85 ;$ CFI $=0.98 ; \mathrm{NFI}=0.96 ;$ IFI $=0.98 ;$ RMSEA $\left.=0.04\right)$. Second, we imposed the restriction of equality of parameters for the two samples and compared the results for goodness of fit in the restricted model to the results for goodness of fit in the unrestricted model. Since model fit did not worsen significantly, measurement invariance is fulfilled. The differences observed between the causal relationship models are thus due to the causal relationships themselves and not to measurement of the constructs.

As common method bias may have confounding effects on the relationships observed among the constructs, particularly when data are self-reported (as in this study), the singlecommon-method factor approach was used to test for common method bias [10]. The measurement model was estimated with a single-method first-order factor added to all indicators of the latent variables. The fit indices (CFI, NFI, and RMSEA) in the commonmethod factor model were similar to those in the basic model, and the correlation estimates between the constructs remained unchanged between the two models [73]. On the basis of these results, common method bias was not considered to be a problem in the research.

\subsection{Causal Relationship Model}

We estimate the model in Figure 1 using structural equations modeling, without including the moderating effect. The fit obtained is satisfactory $\left(\chi^{2}=156.23\right.$; d.f. $=76$; $\chi^{2} /$ d.f. $\left.=2.05 ; \mathrm{CFI}=0.99 ; \mathrm{NFI}=0.98 ; \mathrm{IFI}=0.99 ; \mathrm{GFI}=0.97 ; \mathrm{AGFI}=0.95 ; \mathrm{RMSEA}=0.04\right)$, and all proposed hypotheses are confirmed. Figure 2 presents the path coefficients for the overall model. We observe that the functional value provided by the virtual community is a key antecedent to stimulating both components of value co-creation (H1a and H1b). Further, self-value co-creation of the experience in which the user engages in the virtual community and participation in that experience relative to other users (communal-value co-creation) encourage the community's BE (H2a and $\mathrm{H} 2 \mathrm{~b})$. 


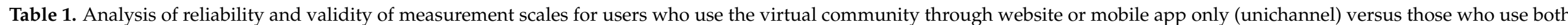
channels (multichannel).

\begin{tabular}{|c|c|c|c|c|c|c|c|c|c|c|c|c|c|}
\hline & \multirow{3}{*}{ Variables } & \multirow{2}{*}{\multicolumn{2}{|c|}{$\mathbf{L}_{\mathrm{i}}$}} & \multirow{2}{*}{\multicolumn{2}{|c|}{$E_{i}$}} & \multicolumn{4}{|c|}{ Reliability } & \multicolumn{4}{|c|}{ Validity } \\
\hline & & & & & & \multicolumn{2}{|c|}{ Cronbach's Alpha } & \multicolumn{2}{|c|}{$\begin{array}{c}\text { Composite } \\
\text { Reliability (CR) }\end{array}$} & \multicolumn{2}{|c|}{$\begin{array}{l}\text { Average Variance } \\
\text { Extracted (AVE) }\end{array}$} & \multicolumn{2}{|c|}{ Convergent Validity } \\
\hline & & Uni & Multi & Uni & Multi & Uni & Multi & Uni & Multi & Uni & Multi & Uni & Multi \\
\hline $\begin{array}{l}\text { Functional value. Tripadvisor } \\
\text { lets me: }\end{array}$ & $\begin{array}{l}\mathrm{v}_{1} \text { : Find services that fit my interests } \\
\mathrm{v}_{2} \text { : Choose the service I need } \\
\mathrm{v}_{3} \text { : Get ideas to plan my experiences }\end{array}$ & $\begin{array}{l}0.82 \\
0.77 \\
0.68\end{array}$ & $\begin{array}{l}0.80 \\
0.90 \\
0.74\end{array}$ & $\begin{array}{l}0.33 \\
0.41 \\
0.54\end{array}$ & $\begin{array}{l}0.36 \\
0.20 \\
0.46\end{array}$ & 0.80 & 0.85 & 0.80 & 0.85 & 0.58 & 0.66 & $\begin{array}{c}\mathrm{t}=\ldots \\
\mathrm{t}=12.25^{* * *} \\
\mathrm{t}=11.25^{* * *}\end{array}$ & $\begin{array}{c}t=\ldots \\
t=13.12 \\
t=11.73\end{array}$ \\
\hline $\begin{array}{l}\text { Self-value co-creation. When } \\
\text { thinking about the experiences } \\
\text { you have } \\
\text { evaluated/commented on } \\
\text { Tripadvisor }\end{array}$ & $\begin{array}{l}\mathrm{v}_{4}: \text { I participate actively in organization } \\
\text { of my experiences } \\
\mathrm{v}_{5} \text { : I consider comments from other users } \\
\text { to organize my experiences } \\
\mathrm{v}_{6} \text { : I get involved in the whole } \\
\text { organization process }\end{array}$ & $\begin{array}{l}0.86 \\
0.85 \\
0.68\end{array}$ & $\begin{array}{l}0.74 \\
0.77 \\
0.61\end{array}$ & $\begin{array}{l}0.26 \\
0.27 \\
0.58\end{array}$ & $\begin{array}{l}0.45 \\
0.41 \\
0.53\end{array}$ & 0.74 & 0.74 & 0.79 & 0.75 & 0.57 & 0.51 & $\begin{array}{c}\mathrm{t}=\ldots \\
\mathrm{t}=15.19^{* * *} \\
\mathrm{t}=8.68^{* * *}\end{array}$ & $\begin{array}{c}t=\ldots \\
t=9.08^{* * *} \\
t=7.81^{* * *}\end{array}$ \\
\hline $\begin{array}{l}\text { Communal-value co-creation. } \\
\text { When I express an opinion about } \\
\text { an experience on Tripadvisor: }\end{array}$ & 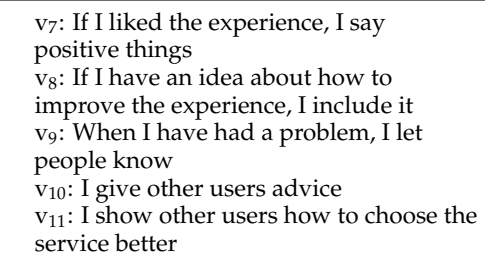 & $\begin{array}{l}0.78 \\
0.73 \\
0.77 \\
0.87 \\
0.92\end{array}$ & $\begin{array}{l}0.78 \\
0.79 \\
\\
0.64 \\
0.86 \\
0.89\end{array}$ & $\begin{array}{l}0.38 \\
0.47 \\
0.40 \\
0.24 \\
0.15\end{array}$ & $\begin{array}{l}0.39 \\
0.38 \\
0.59 \\
0.26 \\
0.21\end{array}$ & 0.93 & 0.91 & 0.91 & 0.90 & 0.67 & 0.64 & $\begin{array}{c}t=\ldots \\
t=12.17^{* * *} \\
t=16.11^{* * *} \\
t=18.23^{* * *} \\
t=18.35^{* * *}\end{array}$ & $\begin{array}{c}t=\ldots \\
t=7.26^{* * *} \\
t=7.09^{* * *} \\
t=14.19^{* * *} \\
t=14.20^{* * *}\end{array}$ \\
\hline Virtual community СВBE & $\begin{array}{l}\mathrm{v}_{12}: \text { I prefer using Tripadvisor to other } \\
\text { brands that provide similar services } \\
\mathrm{v}_{13}: \text { Although another brand has the } \\
\text { same characteristics as Tripadvisor, I } \\
\text { prefer to use Tripadvisor } \\
\mathrm{v}_{14}: \text { Although Tripadvisor is no different } \\
\text { from other brands, it seems good to } \\
\text { use Tripadvisor } \\
\mathrm{v}_{15}: \text { I like Tripadvisor better than other } \\
\text { similar brands }\end{array}$ & $\begin{array}{l}0.91 \\
0.90\end{array}$ & 0.92 & $\begin{array}{l}0.17 \\
0.20\end{array}$ & $\begin{array}{l}0.23 \\
0.25\end{array}$ & 0.95 & 0.93 & 0.95 & 0.94 & 0.84 & 0.77 & $\begin{array}{c}t=\ldots \\
t=26.18^{* * *} \\
t=27.60^{* * *} \\
t=27.35^{* * *}\end{array}$ & $\begin{array}{c}t=\ldots \\
t=18.21 * * * \\
t=16.60 * * * \\
t=19.87^{* * * *}\end{array}$ \\
\hline
\end{tabular}


Table 2. Analysis of discriminant validity for both pairs of samples (unichannel vs. multichannel users) by average variance method.

\begin{tabular}{|c|c|c|c|c|c|}
\hline Variables & Segments & Functional Value & $\begin{array}{l}\text { Self-Value } \\
\text { Co-Creation }\end{array}$ & $\begin{array}{c}\text { Communal-Value } \\
\text { Co-Creation }\end{array}$ & $\begin{array}{l}\text { Virtual Community } \\
\text { CBBE }\end{array}$ \\
\hline Functional value & $\begin{array}{l}\text { uni-channel } \\
\text { multi-channel }\end{array}$ & $\begin{array}{l}0.76 \\
0.81\end{array}$ & & & \\
\hline $\begin{array}{l}\text { Self-value } \\
\text { co-creation }\end{array}$ & $\begin{array}{l}\text { uni-channel } \\
\text { multi-channel }\end{array}$ & $\begin{array}{l}0.46 \\
0.48\end{array}$ & $\begin{array}{l}0.75 \\
0.71\end{array}$ & & \\
\hline $\begin{array}{c}\text { Communal-value } \\
\text { co-creation }\end{array}$ & $\begin{array}{l}\text { uni-channel } \\
\text { multi-channel }\end{array}$ & $\begin{array}{l}0.38 \\
0.34\end{array}$ & $\begin{array}{l}0.44 \\
0.23\end{array}$ & $\begin{array}{l}0.82 \\
0.80\end{array}$ & \\
\hline $\begin{array}{l}\text { Virtual community } \\
\text { CBBE }\end{array}$ & $\begin{array}{l}\text { uni-channel } \\
\text { multi-channel }\end{array}$ & $\begin{array}{l}0.36 \\
0.36\end{array}$ & $\begin{array}{l}0.56 \\
0.57\end{array}$ & $\begin{array}{l}0.62 \\
0.43\end{array}$ & $\begin{array}{l}0.92 \\
0.88\end{array}$ \\
\hline
\end{tabular}

Note: Values in bold on the diagonal correspond to the square root of the average variance extracted in each construct. Values below the diagonal represent the correlations between pairs of constructs. Unichannel: Users in the virtual community who access the same good through either the website or the mobile app. Multichannel users: Users in the virtual community who access the same good through the website and through the mobile app.

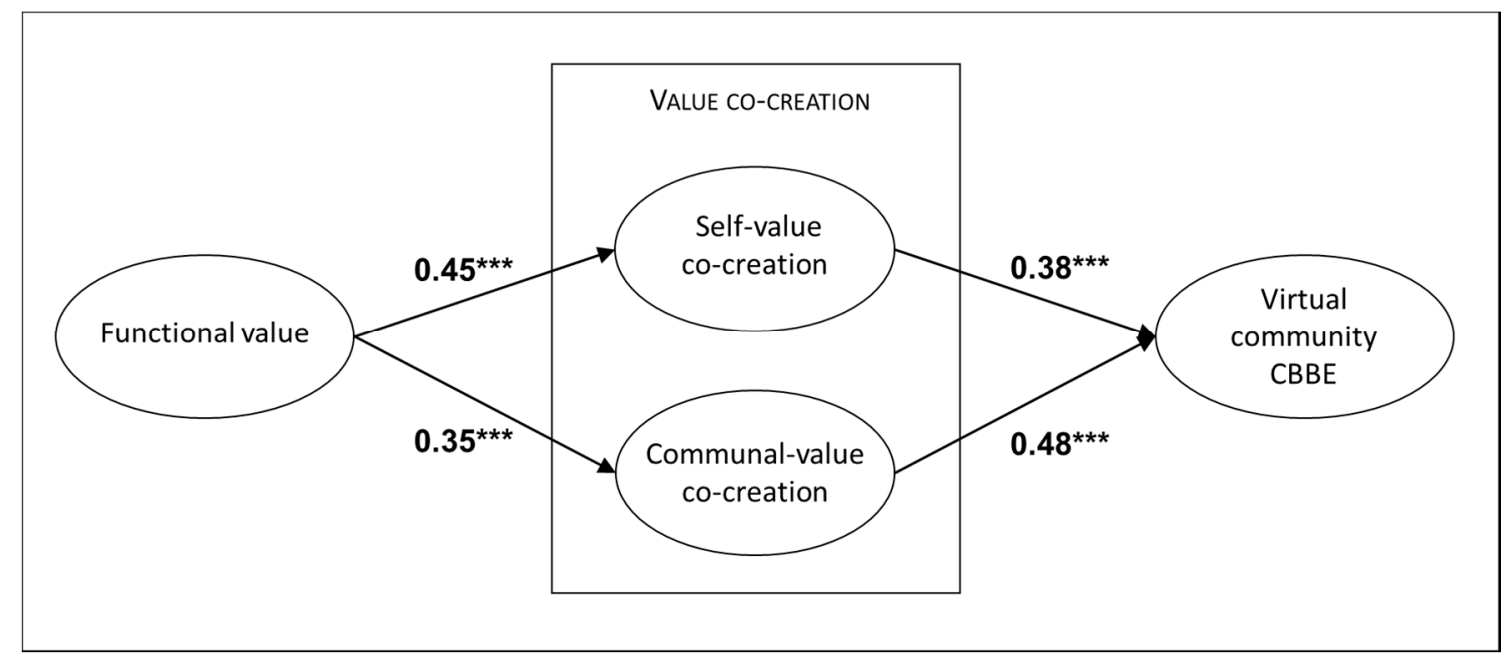

Figure 2. Estimation of causal model. ${ }^{* *} p<0.01$.

We now analyze the moderating effect and perform a multigroup structural analysis for users who participate in the virtual community through a single channel (website or mobile app), as opposed to those who use both channels. We compare the results of the two models - the first, unrestricted model and a second model, on which we impose the restriction of equality for the structural parameters in the two segments (restricted model). The results for goodness of fit show significant worsening in the model when we impose restrictions of equality on the structural relationships These findings indicate significant differences in some of the structural relationships proposed in the theoretical model, depending on the choice of channels used to participate in the virtual community.

More specifically, the effect of communal-value co-creation in the virtual community on the community's BE is significantly stronger in the segment of users who participate only through the community's webpage or only through its mobile app ( $\beta=0.53^{* * *}$ in the unichannel segment vs. $\beta=0.33^{* * *}$ in the multichannel segment) (see Figure 3 ). These results are discussed in the next section. 


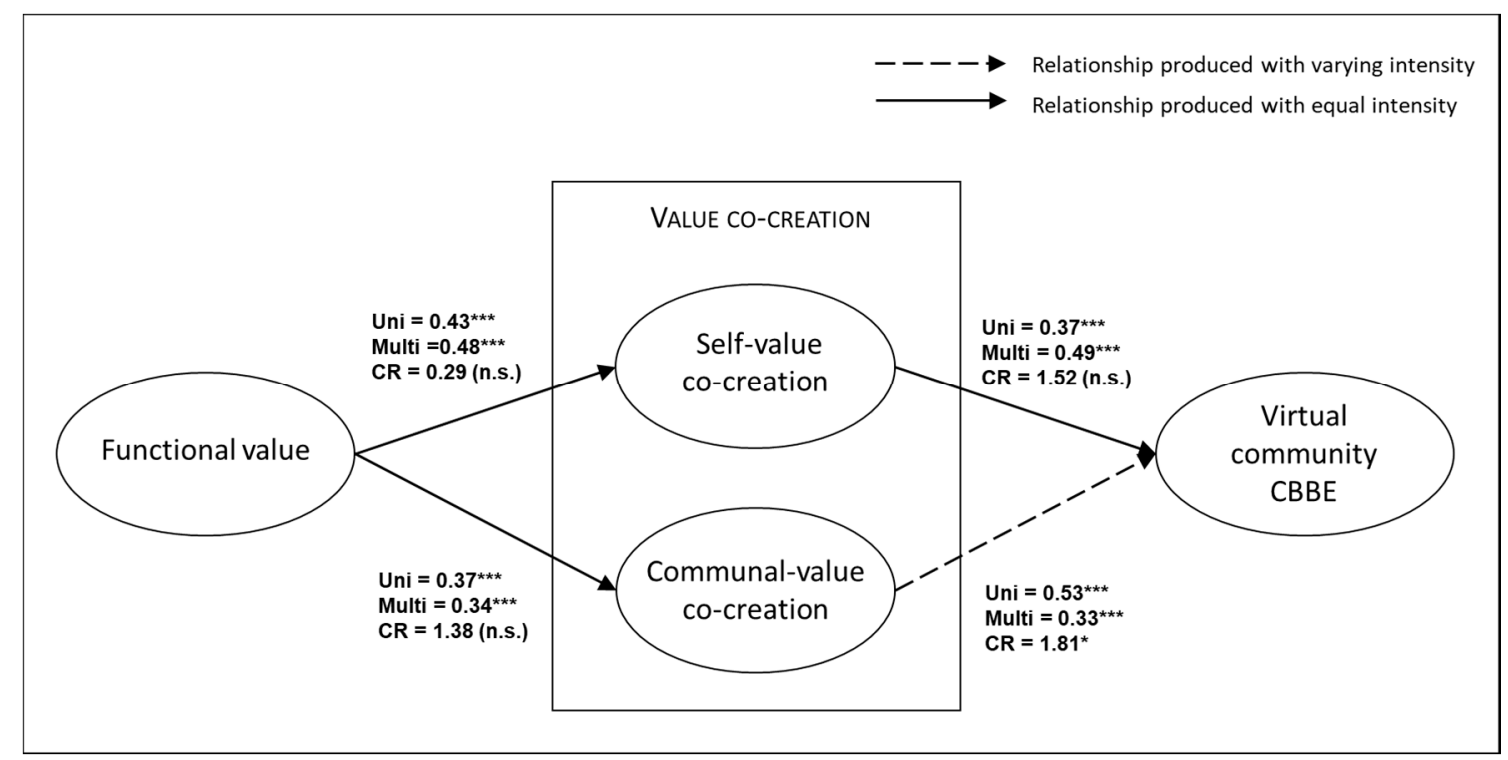

Figure 3. Results of multigroup analysis for unichannel users vs. multichannel users. Uni = Access to virtual community through either website or mobile app; Multi = Access to virtual community through website and mobile app. ${ }^{* *} p<0.01$; ${ }^{*} p<0.1 ;$ n.s. $=$ not significant; C.R.: Critical ratio for differences between parameters. $\mathrm{t}=1.65$ for ${ }^{*} p<0.10$ and $\mathrm{t}=2.58$ for $* * * p<0.01$.

We also analyzed the possible differences for users of the virtual community who access it through a single channel and found that the type of channel used (website vs. mobile app) has a moderating effect on the relationship between the dimensions of cocreation and brand equity. Table 3 presents these results.

Table 3. Results of multigroup analysis for Website users vs. Mobile app users.

\begin{tabular}{ccc}
\hline & Website & Mobile App \\
\hline Self-value co-creation $\rightarrow$ Virtual community CBBE & $0.41^{* * *}$ & 0.17 (n.s.) \\
\hline Communal-value co-creation $\rightarrow$ Virtual community CBBE & $0.54^{* * *}$ & $0.47^{* * *}$ \\
\hline
\end{tabular}

Note: ${ }^{* * *} p<0.01 ;$ n.s. $=$ not significant.

The results displayed in Table 3 confirm that using the website to access the virtual community has a positive moderating effect on the relationship between self-value cocreation and virtual community CBBE. No significant difference in effect is observed, however, between website vs. mobile app users in the relationship established between communal-value co-creation and virtual community CBBE.

Finally, we stress the high proportion of variance in the dependent variable explained in both groups. For the group that uses both platforms, we obtained an $\mathrm{R}^{2}$ of 0.41 for virtual community CBBE. For the group that uses only one channel (website or mobile app), $R^{2}$ was 0.48 .

\section{Discussion}

This study confirms the conceptual framework proposed. First, the results obtained provide evidence that the perceived functional value of a virtual community positively influences its users' participation in the process of value co-creation. The results also confirm the positive impact of value co-creation behaviors on the virtual community's CBBE, reinforcing prior studies that point in this direction [55].

According to [39,74], virtual communities are ideal contexts for studying co-creation. They encourage an ecosystem in which value is co-created or "jointly created" by multiple actors-for example, firms and customers-always including the beneficiary (premises 6 and 10, respectively) [14]. Following this premise of SDL, our study enriches prior re- 
search on the co-creation process in virtual communities by identifying two co-creation behaviors that involve all actors mentioned above: (1) self-value co-creation, which represents the user's involvement in design of his/her experience; and (2) communal-value co-creation through the user's active participation in the virtual community, which encourages dialogue and relationships with the other actors who intervene in the community (other consumers, firms). Self-value co-creation is an essential component of co-creation. Thanks to self-value co-creation, actors can develop themselves fully, becoming direct participants in their own co-creation experience by creating value in a way that has meaning for themselves [75]. For example, consumers co-produce when they consult the comments on the virtual community that are most useful/interesting to them and use the comments to plan their tourist experience. On the other hand, participating in the virtual community by making recommendations to potential consumers, providing ideas to service firms, etc., enables these actors (potential consumers, firms) to co-construct personalized value to suit their context. Through the virtual community, therefore, potential consumers consult other users' recommendations and comments to make better decisions and thus to construct value for themselves. Similarly, firms are motivated by the comments and suggestions received to make improvements to services and thus also co-create value.

Second, the study contributes to the existing literature on the influence of multichannelity on the value co-creation process [63] by introducing as moderating variables use of multiple channels of the virtual community vs. use of only one channel. The study examines whether multichannel use to participate in the virtual community of travelers (website or mobile app vs. both channels) changes the intensity of the relationships established between co-creation behaviors and virtual community CBBE. Although we live in a hyperconnected society and a large portion of purchase decisions are made after consulting virtual communities, prior studies in this field have not examined whether the multichannelity enabled by the various channels that virtual communities give their users can increase preference for the virtual community's brand by stimulating the co-creation behaviors that occur in the community [35].

The results of this study show that the positive effect on BE of participation in the virtual community is significantly more intense in the group that participates in the virtual community through a single channel only, whether the website or the mobile app. Communal-value co-creation in the virtual community requires a high degree of cognitive effort, since it is through active participation that users recommend services, contribute novel ideas for improving services, identify errors, make suggestions for improvement, etc. To counteract this cognitive effort, they seek to feel comfortable with the channel used and to have the navigation skills needed. Such comfort generally occurs when they make intensive use of a single channel rather than extensive use of several channels. This finding helps to generalize results along the same lines as the analysis in [54] of a specific case of one brand. Intensive use of one channel increases the individual's degree of expertise with the medium [76]. Thus, the more one participates in the virtual community through a single channel, the better one knows that channel (its interface, its content, how to navigate it). One is therefore more comfortable and perceives greater ability to develop information, creating a virtuous circle that leads to greater preference for that virtual community, with positive repercussions for its BE [77]. Using several channels does not seem to have the same effect on preference for the platform and thus on its BE. One reason could be that the multichannel user perceives imperfect omnichannelity in the channels used, due to perception that the channels lack integration and consistency because of differences in design of the interface, tools available, and use functionalities.

In addition, the unichannel context produces interesting results for the two types of channels examined (website and mobile app). For the segment of website users, selfvalue co-creation has a strong positive effect on preference for the virtual community, but no statistically significant relationship is observed between the variables for mobile app users. These results fit with those of with prior studies indicating that the segment of webpage users who interact intensively with brands during the different phases of the 
shopping process (pre-purchase, purchase, and post-purchase phases) perceive webpages as especially useful and convenient in the information search phase [78]. In this study, self-value co-creation occurs precisely in the phase prior to purchase, as it reflects the value co-creation produced when the user is involved in organization of the experience. Ultimately, the virtual community's website makes the information search process substantially easier for its users, making this stage very convenient and pleasurable. The website strengthens users' participation in self-value co-creation, which contributes to increasing their preference for the virtual community. Managers of the virtual community must pay special attention to the quality of information, navigation structure, and graphic design of their webpages to promote maximum use of this channel, which encourages the positive influence of self-value cocreation in the virtual community CBBE. The webpage's perceived utility and ease of use are crucial factors for promoting users' involvement in preparing their experiences and preference for a specific virtual community for this pursuit.

For users who only use the mobile app, however, self-value cocreation has no influence at all on virtual community CBBE. According to prior research, this is the case because these users do not choose the mobile app to search for information [79]. They use it more in post-purchase phases, for example, to generate feedback on the services to other users. One significant implication for management derived from this result involves fostering use of the mobile app during pre-purchase search for information and preparation of the experience. Such use would increase the virtual community's brand equity derived from self-value co-creation.

Examining the positive influence of communal-value co-creation on virtual community CBBE shows no significant differences between website vs. mobile app users. One implication of this result involves the independence of the channel virtual community users use. Both the website and the mobile app must have interfaces adapted to make it easy and comfortable for their users to write comments, respond to comments, and upload pictures, videos, etc., as their participation in communal-value co-creation will thus strengthen their preference for the virtual community.

The findings also show that, at a specific level of co-creation, using various channels to access the virtual community (website and mobile app) does not generate greater virtual community CBBE than access through a single channel (website or mobile app). Virtual communities must examine the degree of omnichannelity that each of their different channels possesses and make it easy for their users to employ various channels synergically, thus obtaining functional value and transforming this value into higher levels of co-creation.

Since co-creation in the virtual community can produce a positive variable like CBBE, persons in charge of the community must manage this process properly, designing strategies to encourage users to contribute actively to value co-creation. More specifically, involving users in value co-creation depends to a great extent on their perception of the functional value the virtual community provides.

Identifying the factors that improve perception of the platform's functional value is crucial to managing the platform. Among these factors, it is advisable to incorporate elements of personalization that stimulate the participant. Getting users to personalize their experience as much as possible when they access the virtual community increases their perceived utility and gives them a more favorable perception of functional value. The virtual community must thus develop tools to enable its users easily to find services that fit their needs (clear and accessible filters), enable them to create lists to save favorite services, and ultimately design a functional search environment that enables the user to obtain personalized experiences.

Managers of the virtual community must also promote omnichannelity of the different platforms for accessing the virtual community-in this case, the website and mobile app-since each of these platforms reinforces the positive influence of co-creation on the virtual community's BE. The two platforms should be consistent for multichannel users. They should also be integrated and coordinated, since users can then synergically choose 
one or the other to make comments, contribute ideas, etc., according to their experience, preferences, and circumstances.

Based on these results, users co-create value and prefer a specific virtual community when they feel comfortable with the channel used (website/mobile app). Managers of the virtual community are thus advised to orient their strategy to omnichannelity of their channels. They must encourage integration, coordination, and consistency in the brand's different channels to facilitate the multichannel user in making evaluations and comments, contributing ideas, and creating multimedia content on any channel. Ultimately, any action that helps to increase the possibilities for personalizing the virtual channel, its usability, and its ease of use will promote the process of co-creation within it and thus its CBBE.

To conclude, we note some limitations of this study, which can give rise to future lines of research. First, the co-creation behaviors were obtained through responses by survey respondents based on their perceptions. It could generate selection bias (self-selection bias) if there were any difference between respondents and non-respondents. It is thus advisable to follow up by analyzing respondents' real behavior in the virtual community. Likewise, since the study was performed with a group of participants representative of the Spanish market, repetition of the study in other geographic contexts would give it greater external validity. In addition, future research could consider including new antecedents in the proposed modeling (e.g., other motivations of virtual community users, such as hedonic value).

Author Contributions: All authors have contributed equally to this work and have read and agreed to the published version of the manuscript.

Funding: This research was funded by Spanish Ministry of Science and Innovation, grant number PID2020-113561RB-I00 and benefited from the Professorship Excellence Program in accordance with the multi-year agreement signed by the Government of Madrid and the Autonomous University of Madrid (Line\#3).

Conflicts of Interest: The authors declare no conflict of interest.

\section{References}

1. Global Consumer Insights Survey 2020. Available online: https://www.pwc.es/es/retail-consumo/consumer-insights-survey. $\mathrm{html}$ (accessed on 23 April 2021).

2. The Marketing Science Institute 2020. Available online: https:/ /www.msi.org/ (accessed on 20 March 2021).

3. Tonteri, L.; Kosonen, M.; Ellonen, H.K.; Tarkiainen, A. Antecedents of an experienced sense of virtual community. Comput. Hum. Behav. 2011, 27, 2215-2223. [CrossRef]

4. Chou, E.Y.; Lin, C.Y.; Huang, H.C. Fairness and devotion go far: Integrating online justice and value cocreation in virtual communities. Int. J. Inf. Manag. 2016, 36, 60-72. [CrossRef]

5. Chen, A.; Lu, Y.; Chau, P.Y.; Gupta, S. Classifying, measuring, and predicting users' overall active behavior on social networking sites. J. Manag. Inf. Syst. 2014, 31, 213-253. [CrossRef]

6. Zhu, C.; Xu, X.; Zhang, W.; Chen, J.; Evans, R. How health communication via Tik Tok makes a difference: A content analysis of Tik Tok accounts run by Chinese Provincial Health Committees. Int. J. Environ. Res. Public Health 2020, 17, 192. [CrossRef] [PubMed]

7. Okazaki, S.; Li, H.; Hirose, M. Consumer privacy concerns and preference for degree of regulatory control. J. Advert. 2009, 38, 63-77. [CrossRef]

8. Lei, S.I.; Wang, D.; Law, R. Mobile-based value co-creation: Contextual factors towards customer experiences. Tour. Rev. 2021. [CrossRef]

9. Cheung, C.M.; Lee, M.K. Understanding the sustainability of a virtual community: Model development and empirical test. J. Inf. Sci. 2009, 35, 279-298. [CrossRef]

10. Rubio, N.; Villaseñor, N.; Yagüe, M. Sustainable co-creation behavior in a virtual community: Antecedents and moderating effect of participant's perception of own expertise. Sustainability 2020, 12, 8151. [CrossRef]

11. Aquilani, B.; Silvestri, C.; Ruggieri, A. Sustainability, TQM and value co-creation processes: The role of critical success factors. Sustainability 2016, 8, 995. [CrossRef]

12. Casali, G.L.; Perano, M.; Moretta, T.; Zolin, R. How business idea fit affects sustainability and creates opportunities for value co-creation in nascent firms. Sustainability 2018, 10, 189. [CrossRef]

13. Vargo, S.L.; Lusch, R.F. Evolving to a new dominant logic for marketing. J. Mark. 2004, 1, 1-17. [CrossRef] 
14. Vargo, S.L.; Lusch, R.F. Institutions and axioms: An extension and update of service-dominant logic. J. Acad. Mark. Sci. 2016, 44, 5-23. [CrossRef]

15. Hu, M.; Zhang, M.; Luo, N. Understanding participation on video sharing communities: The role of self-construal and community interactivity. Comput. Hum. Behav. 2016, 62, 105-115. [CrossRef]

16. Nambisan, S.; Baron, R.A. Virtual customer environments: Testing a model of voluntary participation in value co-creation activities. J. Prod. Innov. Manag. 2009, 26, 388-406. [CrossRef]

17. Schallehn, H.; Seuring, S.; Strähle, J.; Freise, M. Defining the antecedents of experience co-creation as applied to alternative consumption models. J. Serv. Manag. 2019, 30, 209-251. [CrossRef]

18. Zadeh, A.H.; Zolfagharian, M.; Hofacker, C.F. Customer-customer value co-creation in social media: Conceptualization and antecedents. J. Strateg. Mark. 2019, 27, 283-302. [CrossRef]

19. Ferm, L.E.C.; Thaichon, P. Value co-creation and social media: Investigating antecedents and influencing factors in the US retail banking industry. J. Retail. Consum. Serv. 2021, 61, 102548. [CrossRef]

20. Casaló, L.V.; Flavián, C.; Guinalíu, M. Determinants of the intention to participate in firm-hosted online travel communities and effects on consumer behavioral intentions. Tour. Manag. 2010, 31, 898-911. [CrossRef]

21. Ariño, L.V.C.; Blanco, C.F.; Blasco, M.G. Observación y participación activa en comunidades virtuales comerciales: El caso del sector turismo. Rev. Española Investig. Mark. ESIC 2011, 15, 113-134.

22. Fiol, L.J.C.; García, J.S.; Tena, M.A.M.; Coll, S.F. La importancia de las comunidades virtuales para el análisis del valor de marca: El caso de TripAdvisor en Hong Kong y París. Pap. Tur. 2012, 52, 89-115.

23. Agag, G.; El-Masry, A.A. Understanding consumer intention to participate in online travel community and effects on consumer intention to purchase travel online and WOM: An integration of innovation diffusion theory and TAM with trust. Comput. Hum. Behav. 2016, 60, 97-111. [CrossRef]

24. Füller, J.; Bilgram, V. The moderating effect of personal features on the consequences of an enjoyable co-creation experience. $J$. Prod. Brand Manag. 2017, 26, 386-401. [CrossRef]

25. Franklin, D.; Marshall, R. Adding co-creation as an antecedent condition leading to trust in business-to-business relationships. Ind. Mark. Manag. 2019, 77, 170-181. [CrossRef]

26. Roy, S.K.; Balaji, M.S.; Soutar, G.; Jiang, Y. The antecedents and consequences of value co-creation behaviors in a hotel setting: A two-country study. Cornell Hosp. Q. 2020, 61, 353-368. [CrossRef]

27. Merz, M.A.; Zarantonello, L.; Grappi, S. How valuable are your customers in the brand value co-creation process? The development of a Customer Co-Creation Value (CCCV) scale. J. Bus. Res. 2018, 82, 79-89. [CrossRef]

28. Ranjan, K.R.; Read, S. Value cocreation: Concept and measurement. J. Acad. Mark. Sci. 2016, 44, 290-315. [CrossRef]

29. Vernette, E.; Hamdi-Kidar, L. Cocreation with consumers: Who has the competence and wants to cooperate. Int. J. Mark. Res. 2013, 55, 539-561. [CrossRef]

30. Tsai, H.T.; Pai, P. Explaining members' proactive participation in virtual communities. Int. J. Hum. Comput. Stud. 2013, 71, 475-491. [CrossRef]

31. Xu, B.; Li, D. An empirical study of the motivations for content contribution and community participation in Wikipedia. Inf. Manag. 2015, 52, 275-286. [CrossRef]

32. Sánchez, J.Á.L.; Mieres, C.G.; Vijande, M.L.S. Innovación de servicio y co-creación con los clientes de la empresa: Efectos sobre los resultados. Rev. Española Investig. Mark. ESIC 2013, 17, 79-102. [CrossRef]

33. Bugshan, H. Co-innovation: The role of online communities. J. Strateg. Mark. 2015, 23, 175-186. [CrossRef]

34. Tommasetti, A.; Troisi, O.; Vesci, M. Measuring customer value co-creation behavior: Developing a conceptual model based on service-dominant logic. J. Serv. Theory Pract. 2017, 27, 930-950. [CrossRef]

35. Verleye, K. The co-creation experience from the customer perspective: Its measurement and determinants. J. Serv. Manag. 2015, 26, 321-342. [CrossRef]

36. Holbrook, M.B. Consumer Value: A Framework for Analysis and Research; Psychology Press: New York, NY, USA, 1999.

37. Park, J.; Ha, S. Co-creation of service recovery: Utilitarian and hedonic value and post-recovery responses. J. Retail. Consum. Serv. 2016, 28, 310-316. [CrossRef]

38. Grissemann, U.S.; Stokburger-Sauer, N.E. Customer cocreation of travel services: The role of company support and customer satisfaction with the cocreation performance. Tour. Manag. 2012, 33, 1483-1492. [CrossRef]

39. Füller, J. Refining virtual co-creation from a consumer perspective. Calif. Manag. Rev. 2010, 52, 98-122. [CrossRef]

40. Farquhar, P. Managing brand equity. J. Advert. Res. 1989, 30, 7-12.

41. Aaker, D. Managing Brand Equity: Capitalizing on the Value of a Brand Name; Editorial Free Press, División McMillan Inc.: New York, NY, USA, 1991.

42. Keller, K.L. Conceptualizing, measuring, and managing customer-based brand equity. J. Mark. 1993, 57, 1-22. [CrossRef]

43. Christodoulides, G.; De Chernatony, L. Consumer-based brand equity conceptualisation and measurement: A literature review. Int. J. Mark. Res. 2010, 52, 43-66. [CrossRef]

44. Simon, C.J.; Sullivan, M.W. The measurement and determinants of brand equity: A financial approach. Mark. Sci. 1993, 12, $28-52$. [CrossRef]

45. De Mortanges, C.P.; Van Riel, A. Brand equity and shareholder value. Eur. Manag. J. 2003, 21, 521-527. [CrossRef]

46. Budac, C.; Baltador, L. The value of brand equity. Procedia Econ. Financ. 2013, 6, 444-448. [CrossRef] 
47. Schmitz, A.; Villaseñor-Román, N. Do Brands Matter in Unlisted Firms? An Empirical Study of the Association between Brand Equity and Financial Performance. Adm. Sci. 2018, 8, 65. [CrossRef]

48. Datta, H.; Ailawadi, K.L.; Van Heerde, H.J. How well does consumer-based brand equity align with sales-based brand equity and marketing-mix response? J. Mark. 2017, 81, 1-20. [CrossRef]

49. Kumar, S.R.; Dash, S.; Purwar, C.P. The nature and antecedents of brand equity and its dimensions. Mark. Intell. Plan. 2013, 31, 141-159. [CrossRef]

50. Schivinski, B.; Dabrowski, D. The impact of brand communication on brand equity through Facebook. J. Res. Interact. Mark. 2015, 9, 31-53. [CrossRef]

51. Pham, P.H.; Gammoh, B.S. Characteristics of social-media marketing strategy and customer-based brand equity outcomes: A conceptual model. Int. J. Internet Mark. Advert. 2015, 9, 321-337. [CrossRef]

52. Colicev, A.; Malshe, A.; Pauwels, K. Social media and customer-based brand equity: An empirical investigation in retail industry. Adm. Sci. 2018, 8, 55. [CrossRef]

53. Cheung, M.L.; Pires, G.; Rosenberger III, P.J. Exploring synergetic effects of social-media communication and distribution strategy on consumer-based Brand equity. Asian J. Bus. Res. 2020, 10, 126-149. [CrossRef]

54. Kristal, S.; Baumgarth, C.; Behnke, C.; Henseler, J. Is co-creation really a booster for brand equity? The role of co-creation in observer-based brand equity (OBBE). J. Prod. Brand Manag. 2016, 25, 247-261. [CrossRef]

55. González-Mansilla, Ó.; Berenguer-Contrí, G.; Serra-Cantallops, A. The impact of value co-creation on hotel brand equity and customer satisfaction. Tour. Manag. 2019, 75, 51-65. [CrossRef]

56. Farrokhi, M. Working Together toward a Better Brand: Customer-Based Brand Equity and Co-Creation of Value with Consumers. Ph.D. Thesis, University of Calgary, Calgary, AB, Canada, 2020, unpublished.

57. Zhang, T.C.; Kandampully, J.; Bilgihan, A. Motivations for customer engagement in online co-innovation communities (OCCs): A conceptual framework. J. Hosp. Tour. Technol. 2015, 52, 61-70. [CrossRef]

58. Frias Jamilena, D.M.; Polo Pena, A.I.; Rodriguez Molina, M.A. The effect of value-creation on consumer-based destination brand equity. J. Travel Res. 2017, 56, 1011-1031. [CrossRef]

59. Shen, H.; Li, X.; Zhang, Y. A study on Brand equity of online tourism enterprises based on user value co-creation. Adv. Hosp. Leis. 2018, 14, 111-130.

60. Shang, R.A.; Chen, Y.C.; Liao, H.J. The value of participation in virtual consumer communities on brand loyalty. Internet Res. 2006, 16, 398-418. [CrossRef]

61. Dimmick, J. The Theory of the Niche and Spending on Mass media: The Case of the "Video Revolution". J. Media Econ. 1997, 10, 33-43. [CrossRef]

62. Dimmick, J.; Chen, Y.; Li, Z. Competition between the Internet and traditional news media: The gratification-opportunities niche dimension. J. Media Econ. 2004, 17, 19-33. [CrossRef]

63. Rubio, N.; Villaseñor, N.; Yague, M.J. Does use of different platforms influence the relationship between cocreation value-in-use and participants' cocreation behaviors? An application in third-party managed virtual communities. Complexity 2019, 2019, 7562903. [CrossRef]

64. Parra-López, E.; Bulchand-Gidumal, J.; Gutiérrez-Taño, D.; Díaz-Armas, R. Intentions to use social media in organizing and taking vacation trips. Comput. Hum. Behav. 2011, 27, 640-654. [CrossRef]

65. Kuo, Y.F.; Hu, T.L.; Yang, S.C. Effects of inertia and satisfaction in female online shoppers on repeat-purchase intention: The moderating roles of word-of-mouth and alternative attraction. Manag. Serv. Qual. Int. J. 2013, 23, 168-187. [CrossRef]

66. Chiu, C.M.; Wang, E.T.; Fang, Y.H.; Huang, H.Y. Understanding customers' repeat purchase intentions in B2C e-commerce: The roles of utilitarian value, hedonic value and perceived risk. Inf. Syst. J. 2014, 24, 85-114. [CrossRef]

67. Yi, Y.; Gong, T. Customer value co-creation behavior: Scale development and validation. J. Bus. Res. 2013, 66, 1279-1284. [CrossRef]

68. Yoo, B.; Donthu, N. Developing and validating a multidimensional consumer-based brand equity scale. J. Bus. Res. 2001, 52, 1-14. [CrossRef]

69. Byrne, B.M. Structural equation modeling with AMOS, EQS, and LISREL: Comparative approaches to testing for the factorial validity of a measuring instrument. Int. J. Test. 2001, 1, 55-86. [CrossRef]

70. Bentler, P.M. Fit indexes, Lagrange multipliers, constraint changes and incomplete data in structural models. Multivar. Behav. Res. 1990, 25, 163-172. [CrossRef] [PubMed]

71. Hu, L.T.; Bentler, P.M. Cutoff criteria for fit indexes in covariance structure analysis: Conventional criteria versus new alternatives. Struct. Equ. Modeling A Multidiscip. J. 1998, 6, 1-55. [CrossRef]

72. Hair, J.F., Jr.; Anderson, R.E.; Tatham, R.L.; Black, W.C. Multivariate Data Analysis, 5th ed.; Prentice-Hall: Upper Saddle River, NJ, USA, 1998.

73. Podsakoff, P.M.; MacKenzie, S.B.; Lee, J.Y.; Podsakoff, N.P. Common method biases in behavioral research: A critical review of the literature and recommended remedies. J. Appl. Psychol. 2003, 88, 879. [CrossRef] [PubMed]

74. Kohler, T.; Fueller, J.; Matzler, K.; Stieger, D.; Füller, J. Co-creation in virtual worlds: The design of the user experience. MIS Q. 2011, 36, 773-788. [CrossRef]

75. Prahalad, C.K.; Ramaswamy, V. Co-creation experiences: The next practice in value creation. J. Interact. Mark. 2004, 18, 5-14. [CrossRef] 
76. Alba, J.W.; Chattopadhyay, A. Effects of context and part-category cues on recall of competing brands. J. Mark. Res. 1985, 22, 340-349. [CrossRef]

77. Barrutia, J.M.; Paredes, M.R.; Echebarria, C. Value co-creation in e-commerce contexts: Does product type matter? Eur. J. Mark. 2016, 50, 442-463. [CrossRef]

78. Miquel-Romero, M.J.; Frasquet, M.; Molla-Descals, A. The role of the store in managing postpurchase complaints for omnichannel shoppers. J. Bus. Res. 2020, 109, 288-296. [CrossRef]

79. Tueanrat, Y.; Papagiannidis, S.; Alamanos, E. Going on a journey: A review of the customer journey literature. J. Bus. Res. 2021, 125, 336-353. [CrossRef] 